\title{
Variations in basal conditions on Rutford Ice Stream, West Antarctica
}

\author{
A. M. Sмгтн \\ Ice and Climate Division, British Antarctic Survey, Natural Environment Research Council, High Cross, Madingley Road, \\ Cambridge CB3 OET, England
}

\begin{abstract}
Seismic reflection data from two lines on Rutford Ice Stream are presented and are compared with data already published from a third line on the ice stream. The amplitude and phase of the reflections have been used to investigate the properties of the sub-ice material. Multiple reflections on long record-length data allowed calibration of the reflection coefficient at the ice-bed interface and determination of the acoustic impedance of the bed material. The characteristics of the bed material vary both along and across the ice stream. The average acoustic impedance of the bed material across the glacier at the upstream line is $3.88 \times 10^{6} \mathrm{~kg} \mathrm{~m}^{-2} \mathrm{~s}^{-1}$. This decreases to $3.19 \times 10^{6} \mathrm{~kg} \mathrm{~m}^{2}$ $\mathrm{s}^{-1} 52 \mathrm{~km}$ further downstream. These values are within the range which is typical of soft sediments. Using acoustic impedance as an indicator of subglacial porosity, some areas of the ice-stream bed are interpreted as dilatant water-saturated sediments undergoing pervasive deformation. In other areas, the bed is not deforming and basal sliding may be a more important process. The proportion of the ice-stream width over which bed deformation occurs increases downstream.
\end{abstract}

\section{ICE-STREAM FLOW AND BASAL CONDITIONS}

Ice streams drain as much as $90 \%$ of the ice of the Antarctic ice sheet (Morgan and others, 1982) and flow at velocities which are typically one to two orders of magnitude greater than that of the surrounding ice sheet. Ice-stream flow is largely controlled by friction at the sides and at the bed, with basal conditions relatively more important towards the centre of the ice stream (Frolich and Doake, 1988; Echelmeyer and others, 1994). The fast ice flow which is observed at the surface of an ice stream is believed to be associated with three possible processes occurring at the base: basal sliding; deformation of a soft subglacial bed; and deformation of a region of soft ice forming the lower part of the ice column. These three processes presumably occur in different proportions beneath different ice streams and glaciers and may also vary spatially within an ice stream.

There is little field evidence as to which of these three basal processes actually occur beneath present-day ice streams and in what proportions. Two ice streams where some evidence of the basal conditions exists are Ice Stream B in West Antarctica and Jakobshavns Isbræ in Greenland. Seismic surveys provided evidence for a soft deforming bed beneath Ice Stream B (Fig. 1) (Alley and others, 1986, 1987; Blankenship and others, 1986, 1987b), which was confirmed by subsequent drilling (Engelhardt and others, 1990). In contrast, temperature profiles suggest that deformation of a thick layer of relatively soft basal ice contributes significantly to the fast flow of Jakobshavns Isbrx (Iken and others, 1993). Unlike seismic surveys on Ice Stream B, those on Jakobshavns Isbræ did not detect any clearly defined subice layer (Clarke and Echelmeyer, 1996).

Rutford Ice Stream is a fast-flowing glacier (Fig. 1) which drains ice into the Ronne Ice Shelf. The dynamics of its ice

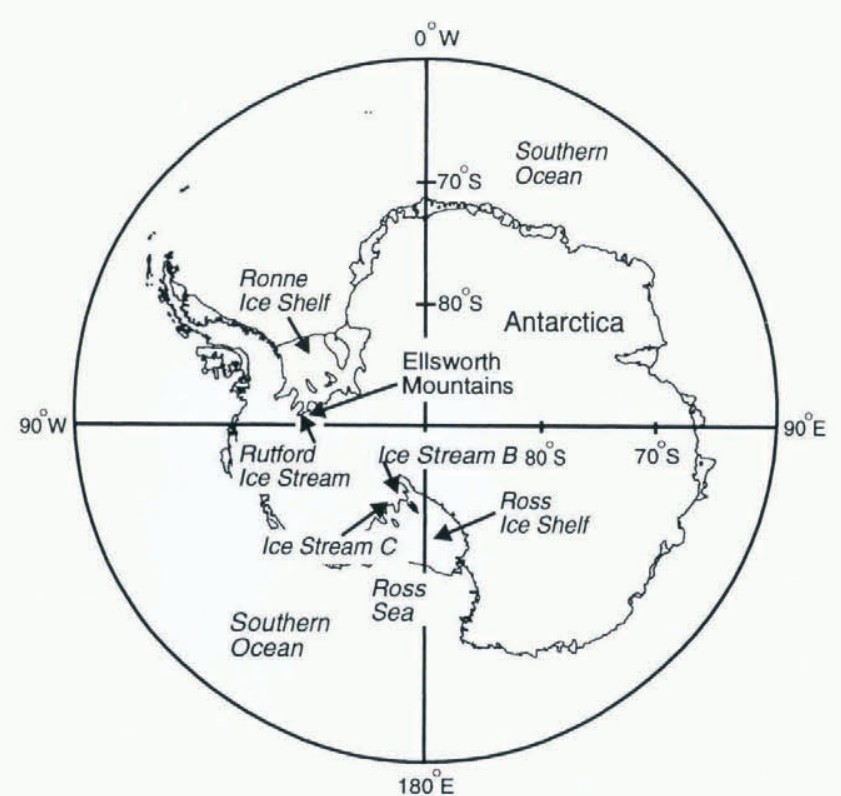

Fig. 1. Location map showing Rutford Ice Stream and other places mentioned in the text.

flow have been described in a number of papers (Stephenson and Doake, 1982; Doake and others, 1987; Frolich and others, 1987, 1989; Frolich and Doake, 1988). Ice velocity is high (300-400 $\mathrm{m} \mathrm{a}^{-1}$; Frolich and others, 1989) and basal shear stress is low (around $40 \mathrm{kPa}$; Frolich and Doake, 1988), so the ice stream is not frozen to the bed and the basal ice is probably close to the pressure-melting point. Active seismic surveys were carried out on Rutford Ice Stream during the 1991 - 92 and 1992 93 field seasons (Smith, 1994) 
with the aim of investigating the basal characteristics and processes and in particular whether basal sliding or softbed deformation was predominant. Smith (1997) presented the results from one seismic reflection line. Two more seismic reflection lines are presented and interpreted here.

\section{CHOICE OF SITES FOR THE SEISMIC SURVEYS}

During the 1992-93 field season seismic reflection data were collected along two lines, New Line and Young Line (Fig. 2), perpendicular to the ice-flow direction. Figure 2 also shows the stake positions of part of the survey network reported in a number of papers (Doake and others, 1987; Frolich and others, 1987, 1989; Frolich and Doake, 1988). The survey data show that the characteristic fast ice flow is already well established in the region of the seismic lines (Doake and others, 1987). The pattern of surface features seen on satellite images suggests that the upstream seismic line (New Line) is positioned about halfway down the length of the icc stream. New Line was $12.6 \mathrm{~km}$ long and Young Line was $3.7 \mathrm{~km}$ long. Young Line is situated in a wide area of relatively smooth and level surface topography seen on satellite images. Surface glaciological measurements in this area (Frolich and others, 1987) indicate that basal shear stress is low $(<40 \mathrm{kPa})$ and that the ice-flow velocity is roughly constant at around $366 \mathrm{ma}^{-1}$. New Line was situated $40 \mathrm{~km}$ further upstream. Satellite images show that the surface topography in the region of New Line is much more undulating, presumably reflecting a rougher ice-stream bed. Basal shear stress and longitudinal surface slope are higher (Frolich and others, 1989); ice-flow velocity is lower (around $310 \mathrm{~m} \mathrm{a}^{-1}$ ) and the longitudinal velocity gradient in the area is positive (Frolich and others, 1989). Figure 2 also shows the position of the seismic line presented by Smith (1997). This line was not named in that source, but here it is called Tyree Line.

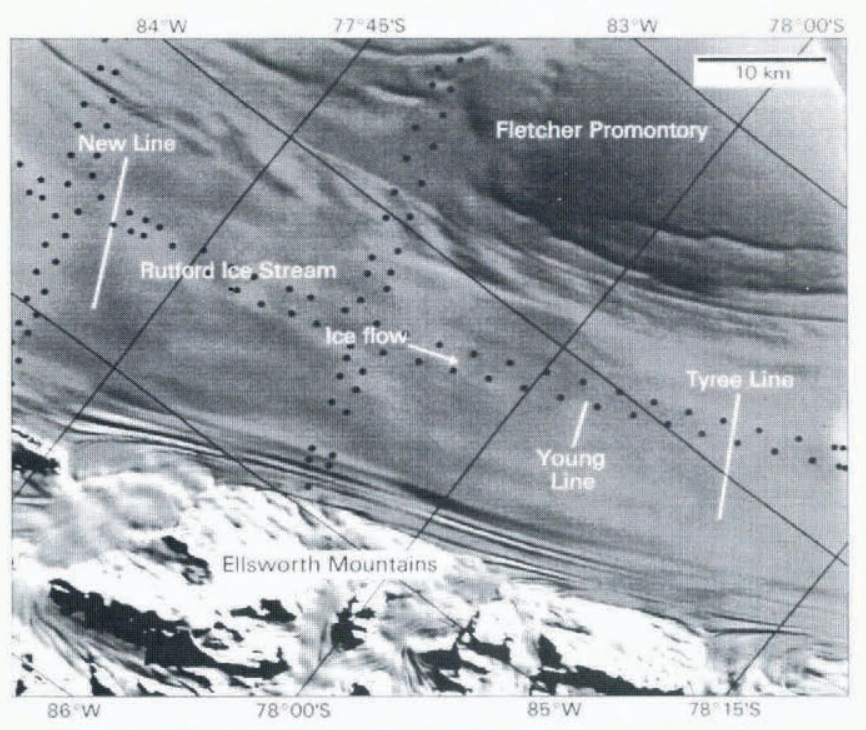

Fig. 2. Layout of the main seismic reflection lines (labelled white lines) on Rutford Ice Stream, 1991-92 and 1992 93 field seasons, superimposed on Landsat satellite image. (Tyree Line was presented by Smith (1997) but was not named in that work.) Black dots mark some of the stake positions of the survey network (Doake and others, 1987; Frolich and others, 1987, 1989; Frolich and Doake, 1988).

\section{SEISMIC ACQUISITION AND DATA PROCESSING}

\section{Seismic reflection surveys}

The acquisition parameters and data processing were the same for both New and Young seismic reflection lines. The seismic source was $300 \mathrm{~g}$ of high explosive, placed in $20 \mathrm{~m}$ deep holes produced with a small hot-water drill. Shots were spaced at $120 \mathrm{~m}$ intervals and were detected by 24 vertically orientated geophones (natural frequency $40 \mathrm{~Hz}$ ) at $10 \mathrm{~m}$ spacing. This produced single fold data with reflection points spaced $5 \mathrm{~m}$ apart on the bed. Offset from the shot to the first geophone was $30 \mathrm{~m}$. The recording instrument (BISON 9024) sampled every $0.2 \mathrm{~ms}$.

The data were adjusted for slight variations in the shot depths and also for the surface topography, assuming that the thickness of the firn was constant along each line. A normal move-out correction was applied, which accounts for the different distances from a given shot to each of the 24 geophones. A predictive deconvolution filter was designed for each shot and applied to remove the surface ghost reflection (this is energy which travels upwards from the shot before bouncing off the surface and going downwards, a short time after the initial downward-travelling shot energy; see Fig. 3). The coefficients and the prediction distance for the deconvolution filter were designed such that the ice-bed reflection was not altered. Finally, the data were migrated to collapse numerous hyperbolas (Smith, 1994) and to position reflections correctly.

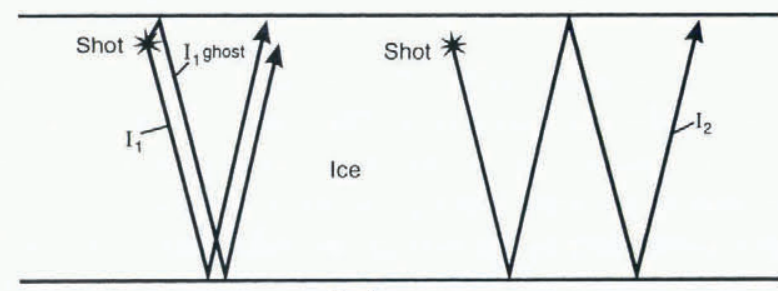

Bed

Fig. 3. Diagrammatic ray-paths for ice bed reflection $\left(\mathrm{I}_{1}\right.$, ice bed ghost ( $\mathrm{I}_{1}$ ghost $)$ and first ice multiple $\left(\mathrm{I}_{2}\right)$.

\section{Wide-angle and shallow refraction surveys}

At a number of sites along both New Line and Young Line, seismic wide-angle and shallow-refraction surveys were conducted to complement the reflection data, as discussed later. The wide-angle experiments recorded data from source-receiver offsets ranging from $10 \mathrm{~m}$ to over $4 \mathrm{~km}$, using charge sizes of $750-2250 \mathrm{~g}$. For the shallow-refraction surveys, small surface sources (either a single detonator or a $50 \mathrm{~g}$ charge) were recorded out to source-receiver offsets of $440 \mathrm{~m}$, to provide information on the velocity and density structure of the upper 100-120 $\mathrm{m}$ of snow and firn.

\section{THE SEISMIC REFLEGTION DATA}

\section{Ice-bed reflections}

The two final processed seismic reflection sections are presented in Figure 4. The arrival labelled $I_{1}$ (after Crary and others, 1962) is the reflection from the base of the ice. Along both lines, this reflection is usually easy to identify, indicat- 

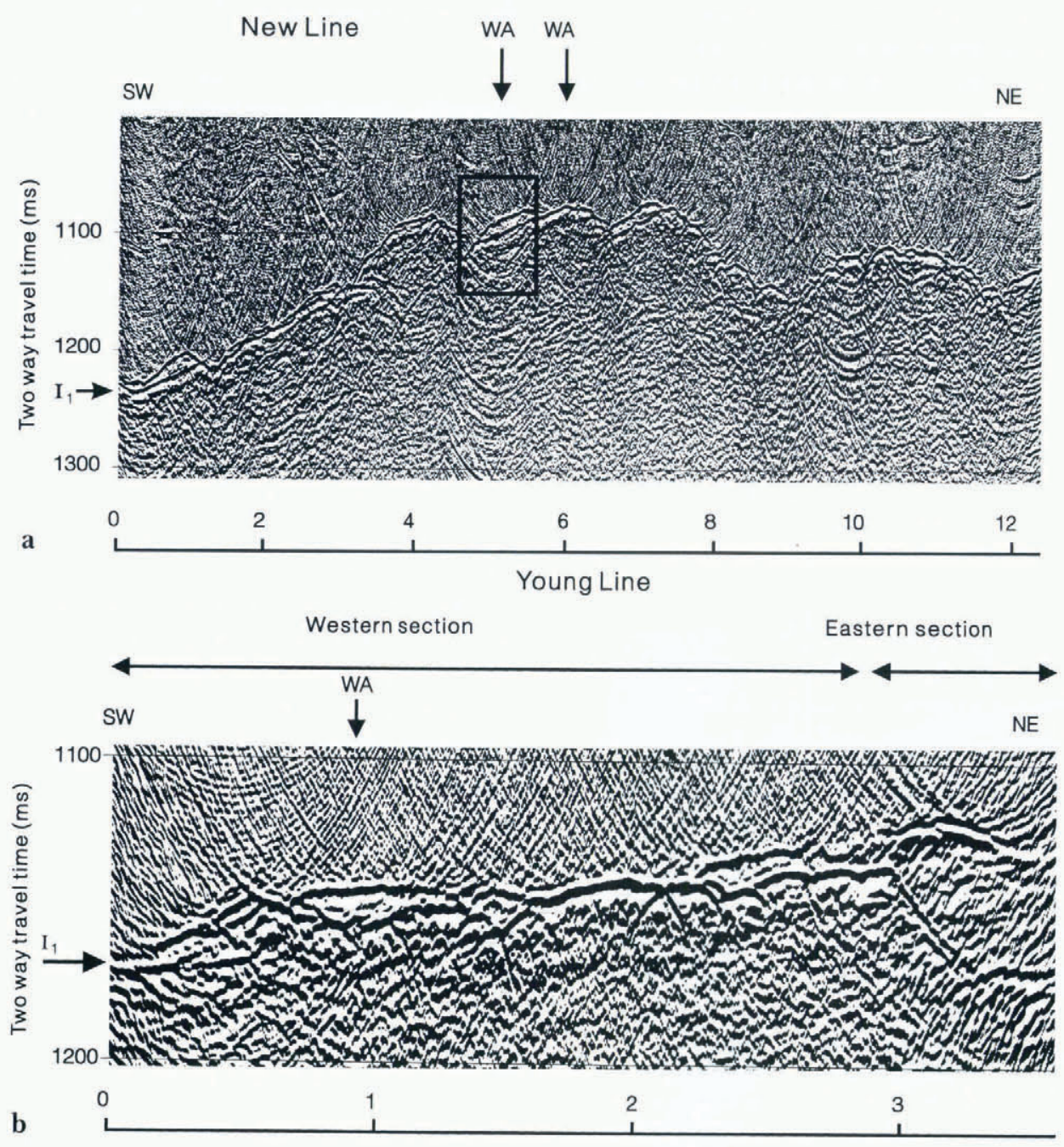

Distance $(\mathrm{km})$

Fig. 4. Processed seismic reflection sections for (a). New Line and (b) Toung Line. (Note the different horizontal and vertical scales.) $\mathrm{I}_{1}$ is the ice bed reflection.WA marks the positions of the wide-angle surveys. Box on. New Line shows the section enlarged in Figure 5. The first part of a normal polarity reflection is white (unfilled); the first part of a reversed polarity reflection is black (filled).

ing a significant acoustic impedance contrast at the ice-bed interface. The acoustic impedance, $Z$, of a medium is defined as:

$$
Z=\rho V
$$

where $\rho$ is its density and $V$ is its seismic velocity. If the acoustic impedance of the bed $\left(Z_{\mathrm{b}}\right)$ is greater than that of the ice $\left(Z_{\mathrm{i}}\right)$, the polarity of the resulting $\mathrm{I}_{1}$ reflection will be normal. Conversely, if $Z_{\mathrm{b}}$ is less than $Z_{\mathrm{i}}$ the resulting $\mathrm{I}_{1}$ reflection will be reversed in polarity. The polarity of the icebed reflections was determined by comparisons with direct waves and with reflections from ice water interfaces, both of which can be predicted. The $I_{1}$ reflection for all of New Line and for most of Young Line is normal polarity. For the eastern end of Young Line, the $I_{1}$ reflection is reversed in polarity. Young Line had been divided into western and eastern sections on this basis (Fig. 4b).

In a number of places along both New Line and Young Line, the normal polarity $I_{1}$ reflection is followed after $10-$ $20 \mathrm{~ms}$ by another strong, normal polarity arrival (labelled $\mathrm{I}_{1}{ }^{\prime}$ in Figure 5). It is not obvious whether this later arrival is a reflection from within the bed or else a reflection from another part of the ice-bed interface, off to one side of the reflection line. A short seismic reflection line was acquired, intersecting New Line and perpendicular to it that is, parallel to the ice flow direction). The acquisition parameters for this additional line were slightly different to those for

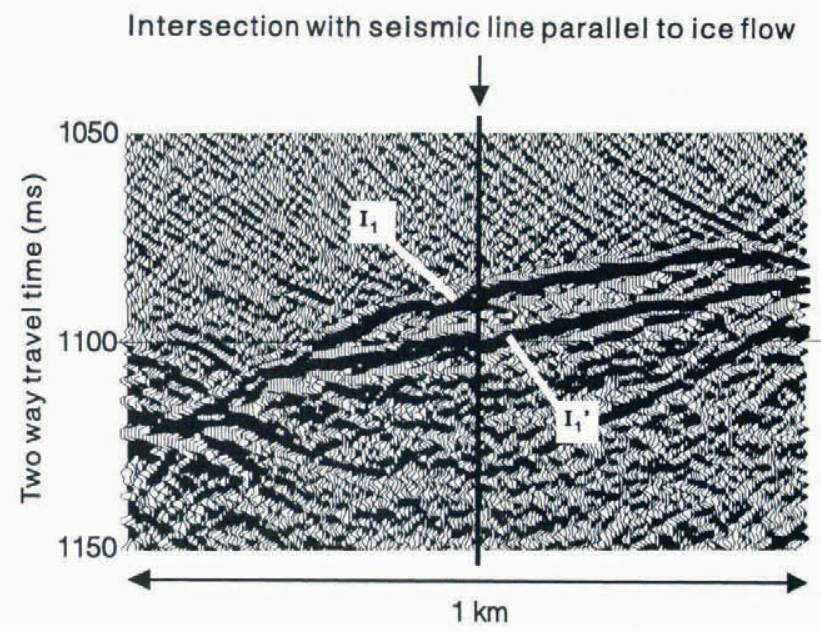

Fig. 5. Enlarged section of ice-bed reflection on New Line, where it intersects with the seismic reflection line parallel to ice flow. $\mathrm{I}_{1}$ is the earlier reflection; $\mathrm{I}_{1}{ }^{\prime}$ is the later one. 
New and Young Lines, resulting in a poorer-quality section. However, study of the $I_{1}$ and $I_{1}$ 'reflections before and after migration (Fig. 6) shows that, at least at this point on New Line, both these arrivals come from the ice-bed interface. One arrival $\left(I_{1}\right)$ comes from the interface directly below the intersection of the two seismic lines, whereas the other $\left(\mathrm{I}_{1}\right)$ comes from a sloping part of the interface, just downstream of the intersection. The similarity between these two arrivals at this point and where they occur elsewhere along New Line suggests that they usually represent two reflections from the ice-bed interface.

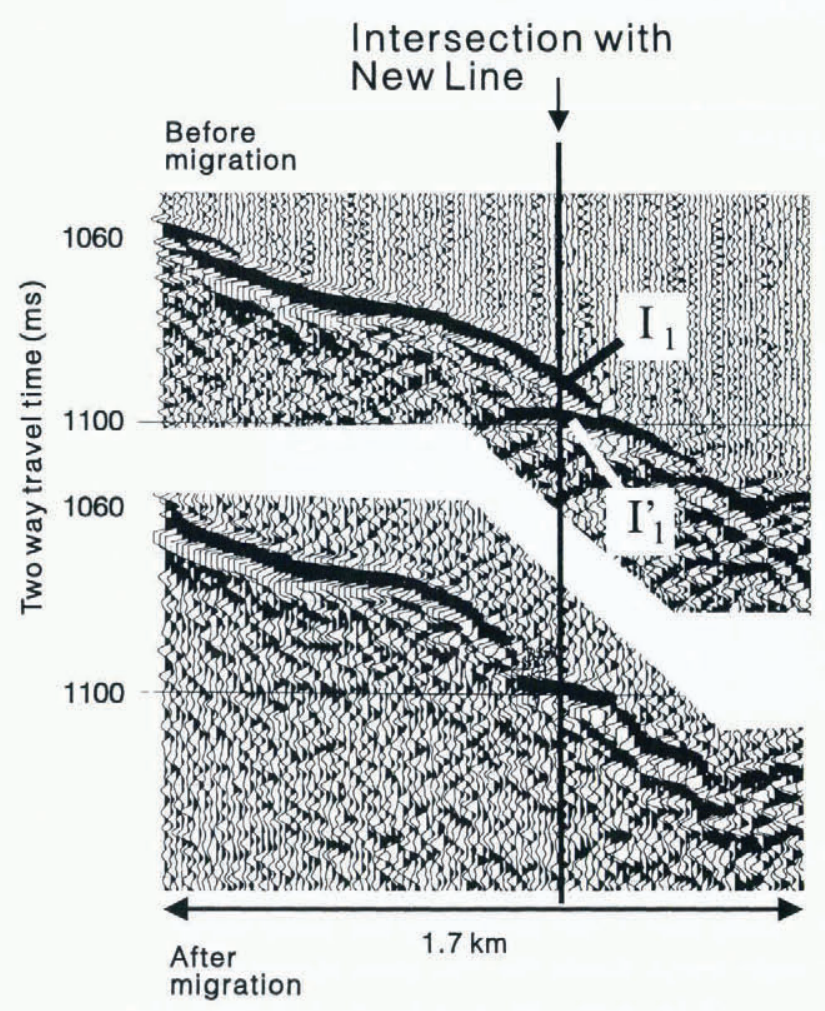

Fig. 6. Part of the seismic reflection section, parallel to ice flow which intersects. New Line. Upper section is before migration; lower section is afterwards. Ice flow is from right to left.

There are strong similarities between this pattern of two arrivals $\left(I_{1}\right.$ and $\left.I_{1}\right)$ on New Line and a similar pattern in places on Young Line (below WA in Figure 4b, for example). This might be taken to suggest that, on Young Line too, both the arrivals come from the ice-bed interface. However, Young Line is much closer to Tyree Line ( $12 \mathrm{~km}$ away) than to New Line $(40 \mathrm{~km})$, and a reflection survey perpendicular to Tyree Line (see Smith, 1996, fig. 3b) showed a very smooth, level bed, very different to that in Figure 6. Hence, although it is likely that the $\mathrm{I}_{1}{ }^{\prime}$ reflections on Young Line do come from the ice-bed interface, this conclusion cannot yet be proved.

In the following analysis the $I_{1}$ reflections are studied in detail. The $\mathrm{I}_{1}{ }^{\prime}$ reflection has not been used in the analysis because of possible corruption by energy immediately following $\mathrm{I}_{1}$. Even where the $\mathrm{I}_{1}{ }^{\prime}$ arrival is actually the one which is directly beneath the seismic line (as in Fig. 6), this is not considered to compromise the analysis, as the reflection points on the bed are close to each other and show reflections of similar strengths.

\section{Ice thickness and bed elevation}

Ice thickness was calculated using a seismic velocity determined in the following way. Reduction of the shallow-refraction seismic experiments, following the method of Kirchner and Bentley (1990), gave a mean seismic velocity of $2839 \mathrm{~m} \mathrm{~s}^{-1}$ for the snow and firn in the upper $100 \mathrm{~m}$ of the ice column (Smith and Doake, 1994). A mean seismic velocity for the rest of the ice column of $3841 \mathrm{~m} \mathrm{~s}^{-1}$ was calculated from Kohnen's (1974) temperature-velocity relationship. This calculation assumed a constant temperature in the upper half of the ice column $\left(-27^{\circ} \mathrm{C}\right.$; Jenkins and Doake, 1991; personal communication from R. M. Frolich, 1996), followed by a linear increase in temperature to the pressure-melting point $\left(-1.5^{\circ} \mathrm{C}\right)$ at the base. The seismic velocity in the ice column is accurate to \pm $15 \mathrm{~m} \mathrm{~s}^{-1}$; ice thicknesses are accurate to $\pm 7 \mathrm{~m}$. Surface elevation above sea level (based on the WGS72 geoid model) was determined by Doppler satellite surveying (accuracy $\pm 5 \mathrm{~m}$ ) at selected locations, combined with standard optical survey techniques. Ice thickness on New Line ranges from $2335 \mathrm{~m}$ at the western end of the line to $2036 \mathrm{~m}$ close to the middle. Bed elevation is lowest $(-1839 \mathrm{~m})$ and highest $(-1540 \mathrm{~m})$ at these two points, respectively (the equal surface elevation at these two points is coincidental). The ice-bed interface of Young Line is smoother. Ice thickness is greatest $(2190 \mathrm{~m})$ at the western end and least $(2121 \mathrm{~m})$ close to the eastern end. Corresponding bed elevations at these points are -1880 and $-1798 \mathrm{~m}$, respectively.

\section{ICE-BED INTERFACE REFLECTION AND ACOUSTIC PROPERTIES OF THE BED}

The seismic sections for New Line and Young Line (Fig. 4) can be used to calculate the strength of the reflection from the ice-bed interface (the reflection coefficient) and some of the acoustic properties of the bed material. The method for doing this is described in detail by Smith (1997) and is presented briefly here.

\section{Reflection coefficient at the ice-bed interface}

The energy $E_{1}$ of an ice bed interface reflection $\mathrm{I}_{1}$ (the energy of a wavelet being the sum of the squared amplitude values) is given by (Roethlisberger, 1972):

$$
E_{1}=\frac{E_{0} R^{2}}{4 h^{2}} \mathrm{e}^{-2 a h}
$$

where $E_{0}$ is the initial energy of the seismic wavelet at the source, $R$ is the reflection coefficient at the ice-bed interface, ice thickness is $h$, and $a$ is the attenuation within the ice. Record lengths for the wide-angle surveys were sufficient to record the first ice multiple reflection $\left(\mathrm{I}_{2} ;\right.$ Figs 3 and 7). Assuming that the reflection coefficient at the snow - air interface is -1, Equation (2) can be used to give the change in energy between the $I_{1}$ and $I_{2}$ reflections (Roethlisberger, 1972):

$$
\frac{E_{1}}{E_{2}}=\frac{4}{R^{2}} \mathrm{e}^{2 a h},
$$

where $E_{2}$ is the wavelet energy of the $\mathrm{I}_{2}$ reflection. Wavelet amplitudes (and hence, energies) on the wide-angle data were measured by identifying the high-amplitude central lobe and the adjacent lobe on each side. Zero-crossings at the start and end of these three lobes were used to delineate the wavelet. 

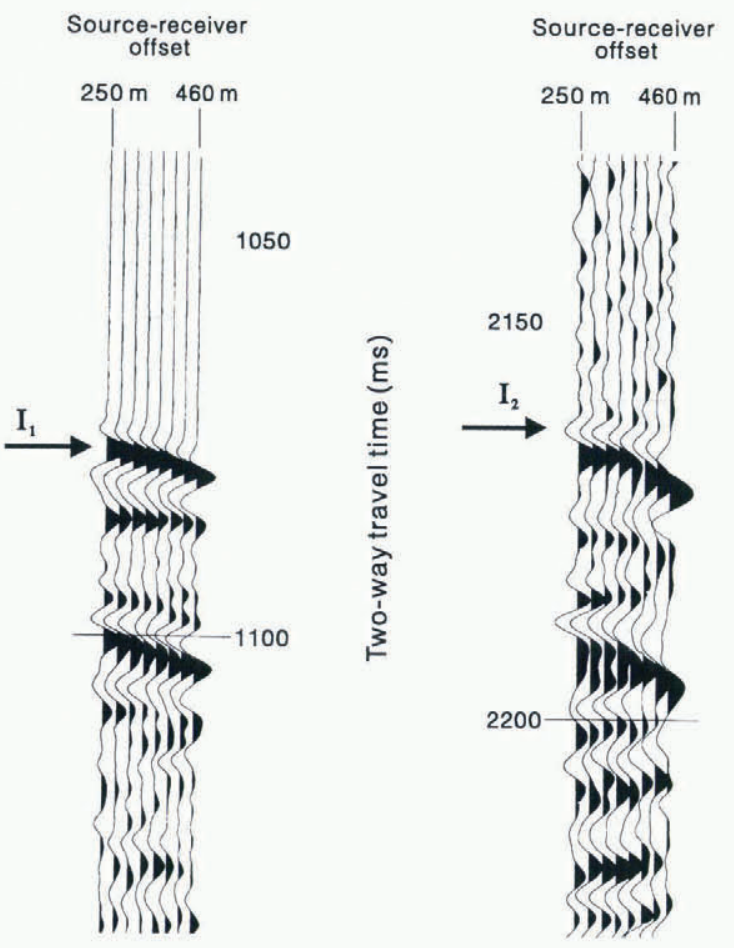

Fig. 7. Example of data from one of the wide-angle surveys showing the $\mathrm{I}_{1}$ and $\mathrm{I}_{2}$ reflections for a single shot. A low-pass filter has been used to remove frequencies greater than $300 \mathrm{~Hz}$ from the traces showing the $\mathrm{I}_{2}$ wavelet. The amplitude of these traces has been increased slightly relative to the $\mathrm{I}_{1}$ reflection, for clarity.

Smith (1997) presented a compilation of attenuation data from a number of sites. Attenuation is related to the ice temperature. Estimating the mean ice-column temperature on Rutford Ice Stream to be $-20^{\circ} \mathrm{C}$ suggests that the correct attenuation value there is $0.21 \times 10^{-3} \mathrm{~m}^{-1}$ (see Smith, 1997, table 1). An error in the estimated mean ice temperature (it could be warmer than $-20^{\circ} \mathrm{C}$ but is unlikely to be colder) would lead to an underestimate of the attenua- tion value. However, a mean ice-column temperature up to $5^{\circ} \mathrm{C}$ warmer than that estimated (the error is unlikely to be greater than this) would lead to the magnitude of the calculated reflection coefficients being too low by less than $10 \%$. Smith (1997) also showed that, even with unrealistically high and low attentuation estimates, the interpretation of reflection coefficients and derived acoustic impedance values remains unaffected.

Equation (3) is strictly only valid for a reflection perpendicular to a plane interface, so only data from geophones relatively close to the shots were used (maximum offset $460 \mathrm{~m}$ ), corresponding to a maximum incident angle of around $6^{\circ}$. At each wide-angle site (two sites on New Line and one on Young Line; Fig. 4), $E_{1} / E_{2}$ was measured from 16 separate seismic traces (8 traces from each of two shots), and a mean value calculated. Using Equation (3), mean values of $R^{2}$ were then calculated for each of the wide-angle sites. From these, $R$ was determined, the sign being given by the observed polarity of the $I_{1}$ reflection.

Knowing the reflection coefficient at the positions of the wide-angle sites, the way it changes along the reflection line can be calculated using the variation in reflection strengths along the line. For each shot on the scismic reflection lines, the $I_{1}$ wavelet on all 24 channels was averaged and its energy $\left(E_{1}\right)$ measured. Knowing $R$ at a wide-angle site allows a value of $E_{0}$ to be calculated from Equation (2), using a value for $E_{1}$ measured from the reflection line at that point. It is necessary to assume that the initial energy is the same for each shot on the reflection line. Although this is unlikely to be strictly correct, as the coupling of the shots with the firn will have varied to some extent, it is reasonable to assume that, for the majority of shots, the initial energy imparted to the firn will be similar. The consistency of the strength of both the $I_{1}$ reflection and the surface ghost (before it was removed) between adjacent shots supports this assumption. $R$ can then be calculated for each shot on the seismic reflection lines. Calculated reflection coefficient values of the ice bed interface along New Line and Young Line are given in Figure 8.

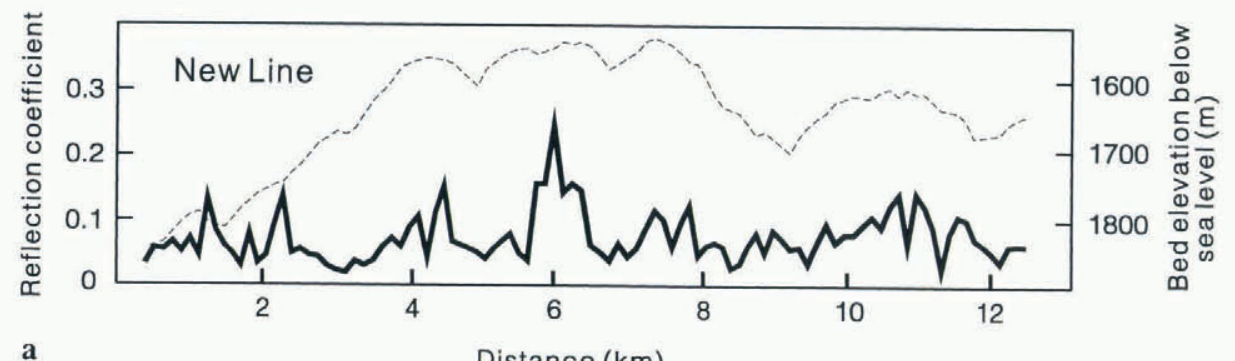

a

Distance $(\mathrm{km})$

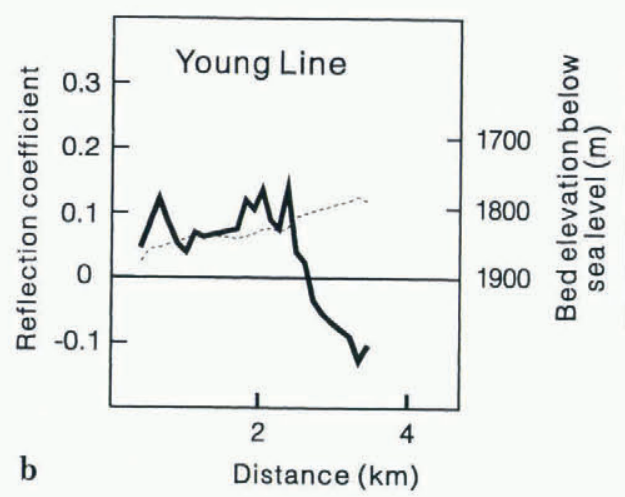

Fig. 8. Reflection coefficient (solid lines) of the ice-bed interface along (a). New Line and (b) Young Line. Dashed lines are the bed elevation profiles. 
An estimate of the accuracy of the derived reflection coefficient values in Figure 8 can be obtained from the two wide-angle sites on New Line. At each site, 16 traces were used to calculate the reflection coefficient, giving a total of 32 separate estimates of the reflection coefficient along the bed of New Line, from which a mean value was calculated. The resulting estimate of the rms error in the reflection coefficients was ${ }_{-0.012}^{+0.023}$. A similar error value was calculated for Young Line, from 16 traces at the single wide-angle site.

\section{Acoustic impedance of the bed: calculation and errors}

The reflection coefficient is related to the acoustic impedances of the ice and the bed $\left(Z_{\mathrm{i}}\right.$ and $Z_{\mathrm{b}}$, respectively) by:

$$
R=\frac{Z_{\mathrm{b}}-Z_{\mathrm{i}}}{Z_{\mathrm{b}}+Z_{\mathrm{i}}}
$$

Using the reflection coefficient data presented in Figure 8, the acoustic impedance of the bed material, $Z_{\mathrm{b}}$, can be calculated from Equation (4) if the acoustic impedance in the ice $Z_{\mathrm{b}}$, is known. Atre and Bentley (1993) discussed the estimation of $Z_{\mathrm{i}}$ in some detail, with particular reference to Ice Stream B, concluding that a value of $(3.33 \pm 0.04) \times 10^{6} \mathrm{~kg}$ $\mathrm{m}^{-2} \mathrm{~s}^{-1}$ was the best estimate. Basal ice temperatures on Rutford Ice Stream and Ice Stream B are expected to be similar and the seismic reflections from the beds of the two ice streams were of similar frequencies $(200-300 \mathrm{~Hz}$; Atre and Bentley, 1993), so Atre and Bentley's value for the acoustic impedance in the ice, $Z_{\mathrm{i}}$, is used here. It is expected to vary little laterally (Atre and Bentley, 1993). The acoustic impedance of the bed along New Line and Young Line can thus be calculated (Fig. 9a and b). The resulting values are similar to those which are typical of soft, water-saturated sediments.

The main sources of error in the calculated acoustic impedance values are the likely errors in the reflection coefficient and the assumed seismic velocities within the ice. These combine to give an rms error in the acoustic impedance of the bed of ${ }_{-0.15}^{+0.25} \times 10^{6} \mathrm{~kg} \mathrm{~m}^{-2} \mathrm{~s}^{-1}$ (where $Z_{\mathrm{b}}>Z_{\mathrm{i}}$ ),
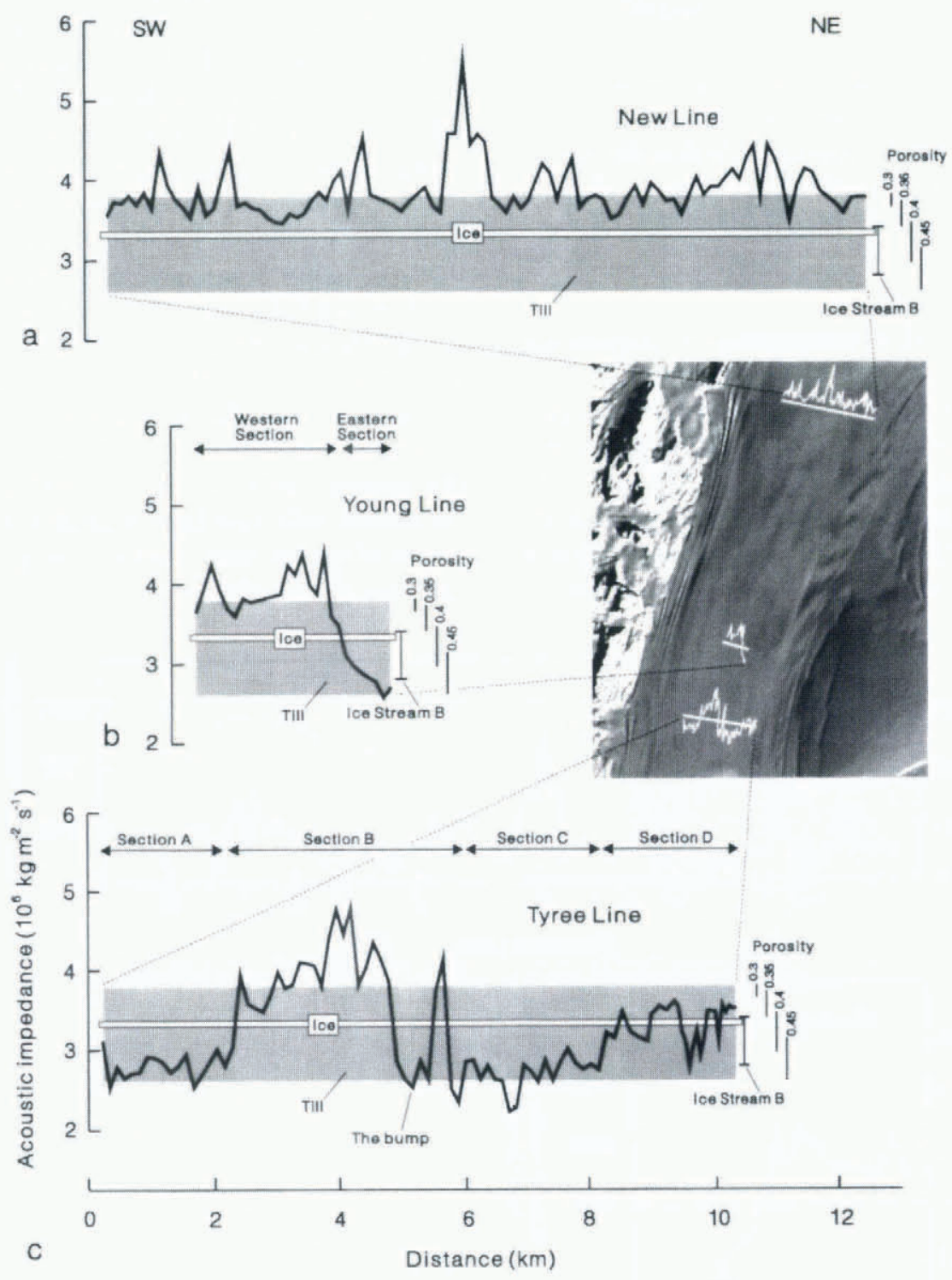

Fig. 9. Acoustic impedance of the bed along (a). New Line, (b) Young Line and (c) Tyree Line (modified from Smith, 1997). The bands labelled "Till" (shaded) and "Ice" (white) and the ranges of porosity values are taken from Atre and Bentley (1993). Vertical bar shows the acoustic impedance of the bed at one site on Ice Stream B (Blankenship and others, 1987b). The satellite image with the line positions and corresponding acoustic impedance plots is the same as that presented in Figure 2 but has been rotated $90^{\circ}$ clockwise. 
though the error can occasionally be more than this where the magnitude of the reflection coefficient is high. The calculated reflection coefficients may also include an unknown systematic error resulting from an underestimate of the attenuation value within the ice. This is unlikely to be greater than $10 \%$ and, as it would lead to the magnitude of reflection coefficients being underestimated, would imply that bed acoustic impedance values differ from those in the ice by even greater amounts than are shown in Figure 9. This means that the interpretation which follows is valid even where the rms error is high and even if there is an unknown systematic error arising from the estimated attenuation value. The overall conclusions arising from the interpretation can therefore be treated with confidence.

\section{INTERPRETATION OF THE ACOUSTIC IMPEDANCE DATA}

\section{Relationship between acoustic impedance and sedi- ment porosity}

Figure 9 also includes likely acoustic impedance values for ice and for water-saturated till. The range of values for till has been taken from data compiled by Atre and Bentley (1993) and includes both deforming and non-deforming (lodged) till. Atre and Bentley (1993) show how the acoustic impedance of likely till material varies for porosity values between 0.3 and 0.45 (see Atre and Bentley, 1993, fig. 12). This range of porosities is expected to be particularly relevant to subglacial sediments. Lodged basal till has a porosity of $\leq 0.3$, whereas shear deformation of saturated sediments causes dilation and an increase in porosity to around 0.4 (Boulton and Dent, 1974; Boulton and others, 1974; Boulton and Paul, 1976). Porosity can thus be used to distinguish between deforming and lodged subglacial till (e.g. Alley and others, 1986, 1987). Corresponding porosity ranges, taken from Atre and Bentley (1993), are included in Figure 9. Smith (1997) proposed that subglacial sediment porosity can be estimated from acoustic impedance. Although this is not a well-constrained relationship it is good enough to distinguish between porosity values of 0.3 and 0.4 . Hence, the acoustic impedance can be used to distinguish between lodged till and till which is dilated and deforming.

\section{New Line}

The acoustic impedance of the bed along New Line (Fig. 9 a) is always greater than that of the ice and is mostly greater than or close to the top of the range for till. Implied porosity is mostly 0.3 or less. It is therefore unlikely that this material is deforming to any significant degree. Ice-stream flow may be influenced more by basal sliding than by subglacial deformation at this site. Figure 10 modified from Smith, 1997, fig. 7) presents a compilation of measured values of velocity and density for saturated, porous sediments and poorly lithified sedimentary rocks. Figure 10 also includes a line of constant acoustic impedance determined from the average value along New Line (Table 1). Where this line intersects the region of values for sediments and rocks shows that the bed of New Line is not only at the upper end of the main range of values for sediments but also at the bottom end of the range for sedimentary rocks. Considering the soft sediment identified elsewhere beneath Rutford Ice Stream

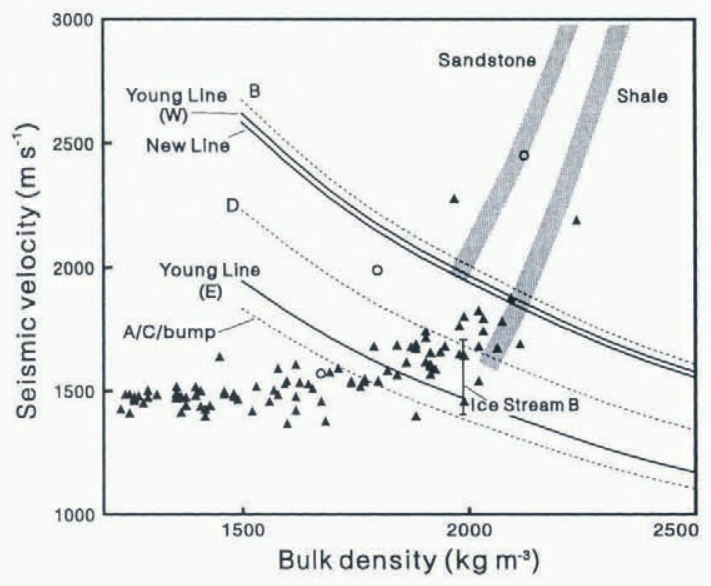

Fig. 10. Published values of density and seismic velocity for sediments and rocks, compared with lines of constant acoustic impedance determined for. New Line and the various sections of loung and Tyree Lines. Modified from Smith (1997). Triangles are from saturated fresh-water sediments and from marine sediments, corrected to fresh-water values (following Blankenship and others, 1987b) where necessary. Sources are Nafe and Drake (1963), Morgan (1969) and Hamilton (1970). Open circles are from poorly lithified Cenozoic rocks from drillholes around McMurdo Sound, Ross Sea (Barrett and Froggatt, 1978). Vertical bar is the velocity and density for the bed of Ice Stream B (Blankenship and others, 1987b). Shaded areas show the lower ends of typical ranges for sedimentary rocks (e.g. Gardner and others, 1974).

Table 1. Mean values of acoustic impedance in the different sections of the bed

\begin{tabular}{ll}
\hline $\begin{array}{l}\text { Location } \\
\end{array}$ & $\begin{array}{c}\text { Mean value of } Z_{\mathrm{b}} \\
10^{6} \mathrm{~kg} \mathrm{~m}^{2} \mathrm{~s}^{-1}\end{array}$ \\
\hline New Line & 3.88 \\
Young Line & \\
Whole line & 3.63 \\
Western section & 3.93 \\
Eastern section & 2.92 \\
Tyree Line & \\
Whole line & 3.19 \\
Sections A, C and the bump & 2.75 \\
Section B & 4.01 \\
Section D & 3.35 \\
Ice Stream B & 3.08 \\
&
\end{tabular}

\footnotetext{
* Blankenship and others (1987b).
}

(Smith, 1997) and also beneath other ice streams (Blankenship and others, 1986; Engelhardt and others, 1990; Clarke and Echelmeyer, 1996), the bed material on New Line is likely to be lodged till rather than poorly lithified sedimentary rock. The data in Figure 10 suggest that the average scismic velocity in the top few metres of the bed material is around $1750-2100 \mathrm{~ms} \mathrm{~s}^{-1}$.

\section{Young Line}

The bed of Young Line has two distinct sections (Fig. 9b): a western section with relatively high acoustic impedance, 
and an eastern section with a much lower acoustic impedance, mostly less than that for ice and at the lower end of the range for till. Implied porosity for the higher-impedance, western section is 0.3 or less, and the average acoustic impedance (Table 1) is very similar to that for New Line, as shown by the curve of the constant acoustic impedance labelled "Young Line (W)" in Figure 10. This suggests a similar interpretation for the western section to that for New Line, namely, a bed of lodged till with an average seismic velocity of around $1750-2100 \mathrm{~m}^{-1}$ in the top few metres of the bed. Acoustic impedance for the bed on the eastern section of Young Line is much less than that in the west (see the line labelled "Young Line (E)" in Figure 10). Implied porosity is around 0.4 or above. Such high porosity is believed to be possible only during sediment deformation (Alley and others, 1986), so the eastern section of Young Line is interpreted as deforming subglacial sediment. This interpretation is supported by the fact that the average acoustic impedance for the eastern part of Young Line is even less than that reported for the till beneath Ice Stream B (Fig. 10; Table 1), which is believed to be deforming (Blankenship and others, 1987b). Seismic velocity in the bed material of the eastern section appears to be around $1500-1700 \mathrm{~m} \mathrm{~s}^{-1}$.

\section{Variations in bed characteristics between the three seismic reflection lines}

Smith (1997) presented a detailed analysis of Tyree Line (Fig. 2), which can be divided into four sections, A-D (Fig. 9c). Two sections, $\mathrm{A}$ and $\mathrm{C}$, have a low acoustic impedance which is believed to indicate subglacial deformation. These two sections are separated by another section, B, with a much higher acoustic impedance, except for a short section of low impedance, referred to as "the bump". In section B, ice flow is believed to be influenced more by basal sliding than by subglacial deformation (Smith, 1997). The bump is believed to be similar to the two sections of subglacial deformation (sections A and $\mathrm{C}$ ). A fourth section, D, has an acoustic impedance between that for section $\mathrm{B}$ and that for the other sections, but is still believed to exhibit subglacial deformation. Lines of constant acoustic impedance for sections B and D and for the mean of A, C and the bump are included in Figure 10.

The pattern of acoustic impedance is very similar on Young Line (Fig. 9b) and on that part of Tyree Line which spans section B and the bump (Fig. 9c). The highest points on both lines show low acoustic impedance values. On Tyree Line this point (the bump) is interpreted as a mound of deforming sediments, tentatively called a subglacial drumlin (Smith, 1997), resting on a harder substrate. Although the corresponding eastern section of Young Line does not appear to lie directly upstream of the bump (see satellite image in Figure 9), it is clearly possible that these two could be a continuous sub-ice feature. The western section of Young Line has a similar acoustic impedance to section B of Tyree Line, as well as to all of New Line (Fig. 10). Hence, although Young Line is relatively short $(3.6 \mathrm{~km})$, the fact that it is situated close to Tyree Line suggests that the pattern of acoustic impedance at the bed beyond both ends of Young Line could be similar to that seen on Tyree Line. The bed in the region of both these lines (Young and Tyree) therefore has areas where significant subglacial deformation is occurring and other areas where it is not.

The similiarities between Young Line and Tyree Line suggest that the boundaries between the areas of different bed character are aligned roughly in the direction of ice flow. Assuming that the highest point on Young Line and the bump on Tyree Line are parts of a straight, continuous feature, then this feature is orientated approximately $10^{\circ}$ to the ice-flow direction. A second estimate of the orientation of bed features, relative to the flow direction, can be made from the hyperbolas which remain on the seismic sections (Fig. 4; Smith, 1997, fig. 3). The fact that a number of hyperbolas remain on the seismic sections after migration could be due to features which are not perpendicular to the seismic line. Re-migration of the sections using a progressively higher velocity value can be used to estimate what the difference in orientation might be. The migration velocity $\left(V_{\mathrm{m}}\right)$ required to collapse a hyperbola is related to the angle between the seismic line and the strike of a feature $(\alpha)$ by:

$$
V_{\mathrm{m}}=\frac{V}{\cos \alpha} \text {. }
$$

In this way, it was determined that some of the features at the bed could be orientated up to $15^{\circ}$ to the direction of the seismic line. Atre and Bentley (1994) found similar orientations of bed features (up to around $20^{\circ}$ ) on the ice plain of Ice Stream B.

The pattern of acoustic impedance on New Line is clearly different to that on both Tyree Line and Young Line. Along most of New Line, there is no evidence for pervasive subglacial sediment deformation. It is therefore similar to only the relatively high-impedance parts of Tyree Line (section B) and Young Line (western section). Further downstream, at Tyree and Young Lines, sediment deformation occurs across a significant proportion of the ice-stream width (almost three-quarters of the width of Tyree Line). Smith's (1997) analysis of Tyree Line concluded that significant variations in bed characteristics occurred across the width of the ice stream. The comparison between Tyree Line, Young Line and New Line shows that significant along-flow variations in bed characteristics also exist on Rutford Ice Stream.

\section{Comparison with ice-bed reflections on Ice Streams $B$ and $C$}

Atre and Bentley $(1993,1994)$ found that seismic reflections from the bed of Ice Streams B and C (Fig. 1) varied between normal and reversed polarity. They also found that, qualitatively, the reversed-polarity reflections ranged from strong to weak, whereas the normal-polarity ones, beneath Ice Stream B at least, were weak. Atre and Bentley (1993) concluded that reflection polarity alone cannot distinguish between a dilated, deforming bed and an undilated, nondeforming one. In contrast to Ice Stream B, the strength of both normal- and reversed-polarity reflections from the bed of Rutford Ice Stream varies from strong to weak. The quantitative analysis of reflection strength shows that the acoustic impedance of some parts of the bed of Rutford Ice Stream is too high for the bed material to be deforming. Combining the reflection polarity analysis with a quantitative amplitude analysis therefore allows the distinction between deforming and non-deforming beds to be be made.

Atre and Bentley (1993) suggested that some of the variations in acoustic impedance at the bed of Ice Streams B and $\mathrm{C}$ could be due to relatively minor changes in the porosity and/or sediment type of a dilatant, deforming bed. This may also explain some of the variations seen within the 
low-impedance parts of the bed of Rutford Ice Stream the difference between sections C and D on Tyree Line, for example). However, such minor changes are insufficient to explain the high-impedance parts of the bed of Rutford Ice Stream. These can be explained by relatively large changes in the porosity and the degree of deformation of the subglacial sediments.

\section{ICE-STREAM BED VARIABILITY AND THE CON- TROLLING MECHANISMS FOR ICE-STREAM FLOW}

Three possible basal processes are believed to be associated with the fast flow of ice streams: (1) pervasive soft-bed deformation, (2) deformation of a basal layer of soft ice at the pressure-melting point, and (3) sliding of ice over the bed, whether lubricated by water or not. The concept of "sticky spots" (e.g. Alley, 1993) is a way of describing the spatial variability of basal conditions. These basal processes are not necessarily mutually independent, but examples exist where each process is believed to be dominant. Soft-bed deformation is believed to be important on the Siple Coast ice streams in West Antarctica, although it is accepted that the full explanation of ice-stream flow there is not simple and requires variations in basal friction (Kamb, 1991; Alley, 1993; Anandakrishnan and Bentley, 1993; Anandakrishnan and Alley, 1994; MacAyeal and others, 1995). Seismic surveys show a lodged till at the bed of Jakobshavns Isbræ, West Greenland (Clarke and Echelmeyer, 1996). However, even though the ice at the bed of Jakobshavns Isbræ is at the melting point, basal sliding appears not to be important and the fast ice flow can be explained by deformation within a layer of soft basal ice (Iken and others, 1993; Clarke and Echelmeyer, 1996). Iverson and others (1995) showed that periods of high ice velocity on Storglaciären, Sweden, were related to high water pressure and low rates of deformation in the bed, leading them to conclude that enhanced ice motion was the result of reduced coupling between the ice and the bed, allowing significant basal sliding to occur.

The different characteristics in the seismic data from Rutford Ice Stream have been used to identify areas where pervasive bed deformation is occurring. Pervasive deformation requires at least some degree of coupling between the ice and the bed to maintain deformation within the sediment and the dilation which results from it. Hence, basal sliding is believed to be less important than bed deformation in these areas. Where the bed is interpreted as lodged till, coupling of the ice with the bed is insufficient to mobilise the bed material to any significant degree. Hence, sliding is more likely than bed deformation. The seismic data cannot establish how important deformation of the basal ice may be. However, the low basal shear stress suggests that it is unlikely to be the major component of ice flow. Hence, understanding why the differences in bed characteristics occur and whether these differences are related to variations in basal friction is important to understanding the ice-stream flow. The differences between areas of the bed which are deforming and those which are not might be expected to be reflected in the pattern of ice flow observed at the surface. Upstream and downstream of the seismic lines, transverse velocity profiles are smooth and undisturbed Frolich and others, 1989), suggesting little correlation with the identified pattern of basal variations. However, whilst the longitudinal surface velocity at New Line is accelerating, it becomes constant before Young and Tyree Lines, possibly reflecting the along-flow changes in basal conditions. Unfortunately, the surface velocity field along the seismic lines is not known well enough to allow a detailed comparison of basal variations and ice flow, but it is interesting to note that there is no clear correlation between the different sections identified at the bed and the surface features on satellite images.

For part of an ice stream to exhibit deformation of a dilatant, saturated sediment at the bed requires the presence of a suitable sediment supply and the presence of water at high pressure - high enough to almost equal the overburden pressure but not enough to actually float the ice. The subglacial sediment is mobilised beneath much of Tyree Line, but not beneath New Line, so the conditions of sediment supply, water supply or effective pressure (the difference between the ice-overburden and the water pressure) probably change over the intervening $52 \mathrm{~km}$. Although other factors (roughness of the till surface, for example) may also influence the degree of deformation, they are probably of lesser importance.

\section{Sediment supply}

The areas of subglacial deformation are evidence that there is a supply of at least some deformable sediment beneath Rutford Ice Stream. It is possible that this represents the total amount of sediment which is available. At the other extreme, it is possible that the whole of the ice-stream bed represents a source of sediment which is available to be mobilised (if not already mobile) under suitable conditions. This latter condition is considered more likely on the basis of the acoustic impedance of the bed material (Figs 9 and 10; Table 1). All of New Line and parts of both Tyree and Young Lines have relatively high acoustic impedance values. However, these values are still low relative to other rock types, even poorly lithified ones. There is probably very little difference between sediments classified as lodged till and those classified as weak sedimentary rocks, in terms of how easily they can be eroded, mobilised and deformed. The implication is therefore that the ice-stream bed beneath all of the seismic lines would be relatively easily deformed, given suitable conditions. It seems likely, though not certain, that lack of available sediment is not the reason for the differences in bed characteristics.

\section{Water supply}

There are a number of reasons why a lack of water at the icestream bed is considered very unlikely. The fast flow of Rutford Ice Stream and low basal shear stress indicate that the ice is not frozen to the bed and that the base must be close to the pressure-melting point. Sources of heat at the bed include geothermal heat flow, strain-heating due to deformation within the ice (or the bed) and friction as the ice slides over the bed. It is likely that the ice at the bed is melting and supplying water to whatever subglacial drainage system may be present. This is supported by the fact that water has been found at the beds of other ice streams (Engelhardt and others, 1990; Iken and others, 1993).

\section{Effective pressure}

It follows that the differences between the bed beneath New Line and that beneath Tyree and Young Lines are probably related to the amounts and distribution of subglacial water 
and the pressure of this water at the ice -bed interface. For deformation to occur, the effective pressure must be low, but not zero. As deformation occurs along much of Tyree Line, the effective pressure there must be low. If the bed material behaves as a Mohr-Coulomb material (Boulton and Hindmarsh, 1987), the effective pressure must be of a similar order of magnitude to the basal shear stress $\left(10^{-}\right.$ $40 \mathrm{kPa}$ at Tyree Line; Frolich and others, 1987) for deformation to occur.

Beneath New Line there is no evidence for deformation. However, the seismic data cannot show whether this is because the effective pressure is too low or too high. If the effective pressure is zero the ice can lift off the bed, removing any coupling across the ice-bed interface and precluding deformation. If, however, the effective pressure is too high, some shearing of the bed may occur but it is not expected to be pervasive and will not be associated with dilation or a significant increase in porosity. Either of these two possibilities would be consistent with the interpretation of the seismic data, but the high basal shear stress at New Line (around $100 \mathrm{kPa}$; Frolich and others, 1987; personal communication from R. M. Frolich, 1996) suggests that the effective pressure there is relatively high and decreases downstream. This decrease could be associated with the accumulation of meltwater and/or changes in the basal drainage system. Alternatively, effective pressure at New Line could be relatively low, with the basal shear stress distributed over localised sticky spots, particularly as bed topography in the region of New Line is relatively rough (Fig. 4a). Basal water pressure may also be very variable on a relatively small scale (Murray and Clarke, 1995). There is still considerable uncertainty in the pattern of effective pressure at the ice-stream bed.

\section{CONCLUSIONS}

The bed of Rutford Ice Stream in the region of the scismic surveys consists of sediments (or, in places, possibly poorly lithified sedimentary rock). The characteristics of the bed vary both along and across the ice stream. In some areas, the sediments are dilated and are undergoing pervasive deformation. In other areas, there is no evidence for deformation, and basal sliding may be a more important process. Seismic velocities within the deforming sediments are estimated to be in the range $1500-1700 \mathrm{~m} \mathrm{~s}^{-1}$, whereas in the non-deforming sediments they are estimated to be around $1750-2100 \mathrm{~m} \mathrm{~s}^{-1}$. The proportion of the ice-stream width exhibiting bed deformation increases downstream (Fig. 11).

The average acoustic impedance value across New Line is $3.88 \times 10^{6} \mathrm{~kg} \mathrm{~m}^{-2} \mathrm{~s}^{-1}$. Across Tyree Line, $52 \mathrm{~km}$ further downstream, it is $3.19 \times 10^{6} \mathrm{~kg} \mathrm{~m}^{-2} \mathrm{~s}^{-1}$. The downstream changes in bed characteristics may be related to variations in the effective pressure, though it is still possible that other factors (e.g. sediment grain-size distribution, degree of lithification, bed roughness, drainage system) are also involved. Alley (1993) suggested that an ice stream with spatially variable basal friction might behave in a fundamentally different way to one with uniform drag. Variations in the basal characteristics of Rutford Ice Stream may be associated with fundamental changes in the basal boundary condition and with different amounts of basal friction. If so, it is difficult to say at present whether this is reflected in the surface velocity field. Further work is needed to investigate any re-
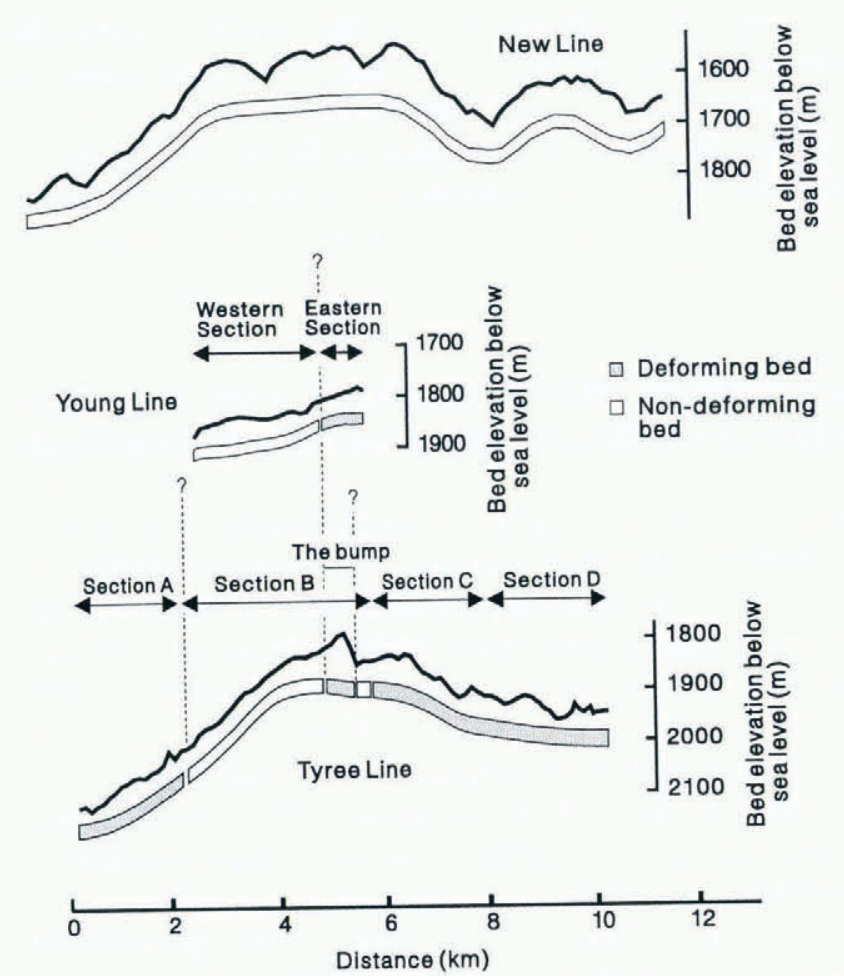

Fig. 11. Areas of bed deformation and basal sliding interpreted from the acoustic impedance data showing downstream and cross-stream variations. Dashed lines show possible correlations between the different sites (they are not meant to imply ice-flow lines). Tyree Line modified from Smith (1997).

lationship between variations in basal conditions and basal friction. One possible way to do this would be to deploy passive seismic monitoring arrays, which have been used successfully in Antarctica on Ice Streams B and C (Blankenship and others, 1987a; Anandakrishnan and Bentley, 1993; Anandakrishnan and Alley, 1994). Using this technique, it may be possible to determine to what degree the different sections of the ice-stream bed are associated with varying amounts of basal friction.

\section{ACKNOWLEDGEMENTS}

I thank S. Abrahams, S. Redshaw and A. Taylor for their help in the field. C. Doake and N. Goulty have provided much guidance throughout this work, which has also benefited from discussions with D. Vaughan, R. Frolich, R. Hindmarsh, G. Clarke, S. Anandakrishnan and D. Blankenship. T. Clarke kindly provided a pre-publication copy of a manuscript.

\section{REFERENCES}

Alley, R. B. 1993. In search of ice-stream sticky spots. f. Glaciol., 39 (133), $447-454$.

Alley, R. B., D. D. Blankenship, C. R. Bentley and S. T. Rooney. 1986. Deformation of till beneath Ice Stream B, West Antarctica. Nature, 322 (6074), 57-59.

Alley, R. B., D. D. Blankenship, C. R. Bentley and S.T. Rooney. 1987. Till beneath Ice Stream B. 3. Till deformation: evidence and implications. 7. Geophys. Res., 92 (B9), 8921-8929.

Anandakrishnan, S. and R. B. Alley. 1994. Ice Stream C, Antarctica, sticky spots detected by microearthquake monitoring. Ann. Glaciol., 20, 183-186.

Anandakrishnan, S. and C. R. Bentley. 1993. Micro-earthquakes beneath Ice Streams B and C, West Antarctica: observations and implications. 
j. Glaciol.. 39 (133), $455-462$.

Atre, S. R. and C. R. Bentley. 1993. Laterally varying basal conditions beneath Ice Streams B and C, West Antarctica. f. Glaciol., 39 (133), 507-514.

Atre, S. R. and C. R. Bentley. 1994. Indication of a dilatant bed near Downstream B Camp, Ice Stream B. Antarctica. Ann. Glaciol., 20, 177-182.

Barrett, P.J. and P. C. Froggatt. 1978. Densities, porosities and seismic velocities of some rocks from Victoria Land, Antarctica. N.Z. .j. Geol. Geophys. $21(2), 175-187$.

Blankenship, D. D., C. R. Bentley, S. T. Rooney and R. B. Alley. 1986. Seismic measurements reveal a saturated porous layer beneath an active Antarctic ice stream. Nature, 322 6074), 54-57.

Blankenship, D. D., S. Anandakrishnan, J. L. Kempf and C. R. Bentley: 1987a. Microearthquakes under and alongside Ice Stream B, Antarctica, detected by a new passive seismic array. Ann. Glaciol., 9, 30-34.

Blankenship, D. D., C. R. Bentley, S. T. Rooney and R. B. Alley. 1987b. Till beneath Ice Stream B. 1. Properties derived from seismic travel times. F) Geophys. Res., 92 (B9), $8903-8911$.

Boulton, G. S. and D. L. Dent. 1974. The nature and rates of post-depositional changes in recently deposited till from south-east Iceland. Geogr. Ann, 56A(3-4), 121-134.

Boulton, G.S. and R. C.A. Hindmarsh. 1987. Sediment deformation beneath glaciers: rheology and geological consequences. J. Geophys. Res., 92 (B9), 9059-9082.

Boulton, G. S. and M. A. Paul. 1976. The influence of genetic processes on some geotechnical properties of glacial tills. Q. f. Eng. Geol., 9, 159-194.

Boulton, G. S., D. L. Dent and E. M. Morris. 1974. Subglacial shearing and crushing, and the role of water pressures in tills from south-cast Iceland. Geogr. Ann., 56A (3-4), 135-145.

Clarke, T. S. and K. Echelmeyer. 1996. Seismic-reflection evidence for a deep subglacial trough beneath Jakobshavns Isbrx, West Greenland. J. Glaciol., 42 (141), 219-232.

Crary, A. P., E. S. Robinson, H. F. Bennett and W. W. Boyd, Jr. 1962. Glaciological studies of the Ross Ice Shelf, Antarctica, 1957-1960. IGT Glaciol. Rep. 6.

Doake, C. S. M., R. M. Frolich, D. R. Mantripp, A. M. Smith and D. G. Vaughan. 1987. Glaciological studies on Rutford Ice Stream, Antarctica. 7. Geophys. Res., 92 (B9), 8951-8960.

Echelmeyer, K. A., W. D. Harrison, C. Larsen and J. E. Mitchell. 1994. The role of the margins in the dynamics of an active ice stream. J. Glaciol., $40(136), 527-538$.

Engelhardt, H., N. Humphrey, B. Kamb and M. Fahnestock. 1990. Physical conditions at the base of a fast moving Antarctic ice stream. Science, $248(4951), 57-59$.

Frolich, R. M. and C. S. M. Doake, 1988. Relative importance of lateral and vertical shear on Rutford Ice Stream, Antarctica. Ann. Glaciol, 11, $19-22$.

Frolich, R. M., D. R. Mantripp, D. G. Vaughan and C. S. M. Doake. 1987. Force balance of Rutford Ice Stream, Antarctica. International Association of Hydrological Sciences Publication, 170 Symposium at Vancouver 1987 Physical Basis of Ice Sheet Modelling , 323 - 331.
Frolich, R. M., D. G. Vaughan and C. S. M. Doake. 1989. Flow of Rutford Ice Stream and comparison with Carlson Inlet, Antarctica. Ann. Glaciol., 12, $51-56$.

Gardner, G. H. F., L. W. Gardner and A. R. Gregory. 1974. Formation velocity and density - the diagnostic basics for stratigraphic traps. Geophysics, 39 (6), $770-780$.

Hamilton, E. L. 1970. Sound velocity and related properties of marine sediments, North Pacific. J. Geophys. Res., 75 (23), $4423-4446$.

Iken, A., K. Echelmeyer, W. Harrison and M. Funk. 1993. Mechanisms of fast flow in Jacobshavns Isbra, West Greenland: Part I. Measurements of temperature and water level in deep boreholes. J. Glaciol., 39 (131), 15-25.

Iverson, N. R., B. Hanson, R. LeB. Hooke and P. Jansson. 1995. Flow mechanism of glaciers on soft beds. Science, 267 (5194), 80-81.

Jenkins, A. and C. S. M. Doake. 1991. Ice ocean interaction on Ronne Ice Shelf, Antarctica. J. Geophys. Res., 96 Cl), $791-813$.

Kamb, W. B. 1991. Rheological nonlinearity and flow instability in the deforming bed mechanism of ice stream motion. 7. Geophys. Res., 96 (B10), $16,585-16,595$.

Kirchner, J. F. and C. R. Bentley. 1990. Seismic short-refraction studies using an analytical curve-fitting technique. In Bentley, C. R. and D. E. Hayes, eds. The Ross Ice Shelf: glaciology and geophysics. Washington, DC, American Geophysical Union, 109-126. (Antarctic Research Series 42.

Kohnen, H. 1974. The temperature dependence of seismic waves in ice. $\vec{f}$ Glaciol., 13 67), 144-147.

MacAyeal, D. R., R. A. Bindschadler and T. A. Scambos. 1995. Basal friction of Ice Stream E, West Antarctica. J. Glaciol., 41 (138), 247-262.

Morgan, N. A. 1969. Physical properties of marine sediments as related to seismic velocities. Geophysics, 34 (4), 529-545.

Morgan, V. I., T. H. Jacka, G. J. Akerman and A. L. Clarke. 1982. Outlet glacier and mass-budget studies in Enderby, Kemp and Mac. Robertson lands, Antarctica. Ann. Glaciol., 3, 204-210.

Murray, T. and G. K. C. Clarke. 1995. Black-box modeling of the subglacial water system. J. Geophys. Res., 100 (B7), 10,231-10,245.

Nafe, J. E. and C. L. Drake. 1963. Physical properties of marine sediments. In Hill, M.N., ed.The sea. Vol. 3. New York, etc., John Wiley and Sons, 794-815.

Roethlisberger, H. 1972. Seismic exploration in cold regions. CRREL. Monogr. II-A2a.

Smith, A. M. 1994. Introduction to high resolution scismic surveys on the Rutford Ice Stream. In Ocrter, H., ed. Filchner-Ronne Ice Shelf Programme. Report 7. Bremerhaven, Alfred Wegener Institute for Polar and Marine Research, 39-41.

Smith, A. M. 1996. Ice shelf basal melting at the grounding line, measured from seismic observations. J. Geophys. Res., 101 (C10), 22,749 22,755.

Smith, A. M. 1997. Basal conditions on Rutford Ice Stream, West Antarctica, from seismic observations. J. Geophys. Res., 102 (B1), 543-552.

Smith, A. M. and C. S. M. Doake. 1994. Sea-bed depths at the mouth of Rutford Ice Stream, Antarctica. Ann. Glaciol., 20, $353-356$.

Stephenson, S. N. and C. S. M. Doake. 1982. Dynamic behaviour of Rutford Ice Stream. Ann. Glaciol., 3, 295-299. 